AGRICULTURE AND BIOLOGY JOURNAL OF NORTH AMERICA

ISSN Print: 2151-7517, ISSN Online: 2151-7525, doi:10.5251/abjna.2011.2.3.432.439

(C) 2011, ScienceHu $\beta$, http://www.scihub.org/ABJNA

\title{
Combining ability of grain yield and agronomic traits in diverse maize lines with maize streak virus resistance for Eastern Africa region
}

\author{
Lilian Gichuru ${ }^{1}$, Kiarie Njoroge $^{2^{\star}}$, Jane Ininda ${ }^{3}$, and Lorroki Peter ${ }^{1}$ \\ ${ }^{1}$ Kenya Agricultural Research Institute, Muguga, Kenya \\ ${ }^{2}$ Faculty of Agriculture, University of Nairobi, Kenya \\ ${ }^{3}$ Alliance for a Green Revolution in Africa (AGRA), Nairobi, Kenya \\ *Corresponding author email: knkabuu@yahoo.com (phone: +254724943124)
}

\begin{abstract}
Combining ability of inbred lines is important information in maize hybrid breeding programs incorporating materials from various germplasm sources. This study was conducted with germplasm varying in their maize streak virus (MSV) reaction, genetic, and geographic origin. In a half diallel cross of six parents, general and specific combining abilities were determined for grain yield, days to silking, ear height and MSV disease resistance. The grain yields of the single crosses were significantly higher from those of the hybrid checks, H614 and H513, which are popular varieties. The importance of both GCA (53\%) and SCA (47\%) for grain yield was observed, but a preponderance of GCA existed for days to silking, ear height, and MSV disease resistance. The best general combiners for grain yield and MSV resistance were CML197 (0.92, $\mathrm{p}<0.001)$ and C92 $(-0.61 \mathrm{p}<0.001)$ respectively. The prediction of hybrid performance for grain yield and MSV resistance could be based on GCA alone, but this should be within specific niches since GCA interacted highly with environments. Key words: grain yield, MSV, GCA (general combining ability), SCA (specific combining ability), single crosses
\end{abstract}

Keywords: grain yield, MSV, GCA (general combining ability), SCA (specific combining ability), single crosses

\section{INTRODUCTION}

Maize streak virus disease is considered to be one of the major problems facing maize farmers in Kenya and other African nations (Magenya et al., 2008; Martin and Shepherd, 2009). Many studies suggest that the obvious strategy to reduce maize yield losses caused by MSV would be to develop MSV resistant and/or tolerant cultivars (van Rensburg, 1981; Soto et al., 1982; Shoyinka, 1988). The development of maize germplasm that is resistant to MSV has therefore been the goal of several breeding programs in Africa.

Breeding programs designed to improve grain yield in maize with tolerance to diseases usually require a good knowledge of combining ability of the breeding materials to be used. For effective selection of grain yield and other desirable traits, information on the magnitude of useful genetic variances in the population, in terms of combining ability and heterosis is required (Vacaro et al., 2002). Significantly, however, the resistance to maize streak virus (MSV) of specific crosses cannot always be reliably predicted from pedigree information or by evaluating parental performance (Diallo, 1999).
Excellent resistance to maize streak is available in maize germplasm at various international, regional and national research institutes. Genetic polymorphisms have been observed in several sources of MSV resistance: CML202, CML197, OSU23i, Tzi3, Tzi35, AO76, VHCY, and C390 (Ininda et al., 1999) where sufficient diversity for MSV resistance was observed for further exploitation by breeders. Five of these lines: CML202, CML197, Tzi3 and VHCY were identified for inclusion in the present study. Several studies have documented the usefulness of some of these sources (Rodier et al., 1995; Welz et al., 1998; Pernet et al., 1999a; Pernet et al., 1999b) in breeding for MSV resistance, but information on their yield productivity crossed to locally adapted lines is scanty. Understanding how the different sources of resistance interact in crosses would hasten breeding of high yielding varieties through specific breeding procedures. Further, it will enable development of hybrids and open pollinated varieties that are well adapted to the mid-altitudes of Kenya and East Africa. This study therefore investigated the value of various sources of MSV resistance for favorable alleles in improving grain yield and agronomic performance. 


\section{MATERIALS AND METHODS}

Parental material: The parental lines in this study were developed at the Kenya Agricultural Research Institute (KARI), CIMMYT (International Centre for Maize and Wheat Improvement), CIRAD (Centre International de Recherché Agronomiques pour le
Développement and IITA (International Institute for Tropical Agriculture). The germplasm varied in maturity, grain color and reaction to maize streak virus disease (Table 1).

\section{Crossing and trials:}

Table 1. Germplasm resource and characteristics of the six parents used in the study

\begin{tabular}{lllllll}
\hline Inbred line & Germplasm & Country of & Mid-silk & Grain & Inbreeding level & MSV \\
& resource & Origin & days & Color & & Reaction \\
CML202 & CIMMYT & Zimbabwe & 89 & White & $\mathrm{S}_{4}$ & Resistant \\
CML197 & CIMMYT & Zimbabwe & 91 & White & $\mathrm{S}_{4}$ & Tolerant \\
Tzi3 & IITA & Nigeria & 77 & White & $\mathrm{S}_{2}$ & Tolerant \\
VHCY & Univ. of Cape & South Africa & 72 & Yellow & $\mathrm{S}_{0}$ & Resistant \\
& town & & & & & \\
CIRAD 390-92 & CIRAD & France & 78 & Yellow & $\mathrm{S}_{4}$ & Immune \\
EM11-133 & KARI & Kenya & 85 & White & $\mathrm{S}_{4}$ & Susceptible \\
\hline
\end{tabular}

A half-diallel cross (Griffing, 1956b) was made among the six parents, forming 15 single crosses. The evaluation trials comprised of the 6 parents, 15 single crosses, 2 hybrid checks, and one inbred check, making a total of 24 entries. The trials were planted at three research stations belonging to KARI: Embu (1460 $\mathrm{m}$ asl), Muguga (2095 $\mathrm{m}$ asl), and Kiboko (993 $\mathrm{m}$ asl). Treatments were, arranged in a randomized complete block design replicated three times during the long rains of 2008-2009. The experimental unit for each entry was three $3 \mathrm{~m}$ long rows, $75 \mathrm{~cm}$ apart giving a plant density of 53,000 plants $\mathrm{ha}^{-1}$. Uniform agronomic practices were observed in all locations. Recordings were made for various agronomic traits but reported here are grain yield (GY), days to silking (DTS) (number of days after planting when $50 \%$ of the plants extrude silk), and ear height (EHT) (height between the base of a plant to the insertion of the top-most ear of the same plant). Grain yield per plot was determined at harvest from fresh cob weight, adjusted to $12.5 \%$ moisture content and converted to tonnes per hectare.

MSV disease screening: Artificial inoculation for MSV disease expression was effected in two seasons at KARI Muguga with the Cicadulina mbila colony which was a direct descent from that of Storey and Howland (1967) and Bock (1974). (This colony is used routinely in the maize improvement program at KARI-Muguga). The genotypes were screened using controlled leafhopper (Cicadulina mbila, Naude) infestation protocols modified from Leuschner and Buddenhagen (1980) by Dr. Jackson Njuguna (personal communication). The plants were inoculated at the 3-leaf stage in the field by attaching a small plastic vial with three viruliferous leafhoppers onto distal portions of the youngest leaf. A rating scale of 1 (no symptoms) to 5 (severe streaking with chlorosis) based on the protocol described by Soto et al. (1982) was used. MSV severity was rated on plot basis using the 1-5 scale with half points as follows: $1=$ no symptom on leaves; $1.5=$ very few streaks on leaves; 2= light streak on old leaves, gradually decreasing on young leaves; $2.5=$ light streaking on old and young leaves; $3=$ moderate streaks on old and young leaves; $3.5=$ moderate streaks on old and young leaves and slight stunting; $4=$ severe streaking on $60 \%$ of leaf area, plants stunted; $4.5=$ severe streaking on $75 \%$ of leaf area, plants severely stunted and $5=$ severe streaking on $75 \%$ or more of the leaf area, plants severely stunted, dying or dead.

Statistical analysis: Data across the three locations for all 24 entries were subjected to analysis of variance (ANOVA) and further, the 15 single crosses were analyzed for combining ability using Griffing's fixed effects strategy of method 4 (no parents or reciprocals), and(Griffing,1956b) and applying the following model: $y_{t j k}=k+g_{t}+g_{j}+s_{i j}+\varepsilon_{i k}$,

where the $g_{i}, g_{j}$, and $s_{i j}$ represent the general combining abilities (GCA) of genotypes $i$ and $j$ and 
specific combining ability (SCA) of the cross between genotypes $i$ and $i$, respectively. The sums of squares

of the crosses were partitioned into GCA and SCA and their interaction with environment (i.e., location) estimated. A $t$ - test was used to assess the significance of GCA and SCA effects. The GCA: SCA ratio for estimating the importance of parental GCA in predicting hybrid performance was according to Baker (1978), GCA: SCA $=\sigma_{\mathrm{g}}^{2} /\left(\sigma_{\mathrm{i}}^{2}+\sigma_{2}^{2}\right)$. For

these analyses, the general linear model procedure
(PROC GLM) in SAS (SAS Institute Inc, 1999) was used.

\section{RESULTS AND DISCUSSION}

Grain Yield: High grain yield potential was shown in the experimental single crosses (Table 2 ), where 10 of the 15 single crosses had higher $(p<0.05)$ grain yields than the best hybrid check, H513, which yielded $7.5 \mathrm{t} \mathrm{ha}^{-1}$. The yields for these 10 single crosses ranged from 8.4 to $11.98 \mathrm{t} \mathrm{ha}^{-1}$ and were all significantly $(p<0.05)$ earlier in maturity by days to silking than $\mathrm{H} 614$, a popular hybrid. High heterosis for grain yield was exhibited in the cross CML197 $\mathrm{x}$ CML202 with $11.98 \mathrm{t} \mathrm{ha}^{-1}$, the highest yielding single cross.

Table 2. Means for maize yield, agronomic traits, and MSV disease score for the $15 F_{1}$ crosses, six parents and checks, sorted in descending order for grain yield.

\begin{tabular}{|c|c|c|c|c|c|}
\hline Type & Genotypes & GY & DTS & EHT & MSV \\
\hline Single cross & CML197 X CML202 & 11.98 & 71.44 & 158.67 & 2.22 \\
\hline Single cross & Tzi3 X CML197 & 10.53 & 69 & 141.83 & 2.49 \\
\hline Single cross & C92 X CML197 & 10.36 & 70 & 163.5 & 1.78 \\
\hline Single cross & C92 X EM11-133 & 9.99 & 68.22 & 160.39 & 2.02 \\
\hline Single cross & C92 X CML202 & 9.43 & 68.11 & 150.22 & 1.44 \\
\hline Single cross & EM11-133 X CML202 & 9.34 & 68.56 & 138.89 & 2.47 \\
\hline Single cross & VHCY X CML197 & 9.17 & 68.11 & 143.56 & 2.16 \\
\hline Single cross & Tzi3 X EM11-133 & 9.11 & 66.33 & 137.17 & 2.79 \\
\hline Single cross & VHCY X CML202 & 9.05 & 64 & 125.44 & 2.04 \\
\hline Single cross & Tzi3 X CML202 & 8.79 & 65 & 124.67 & 2.31 \\
\hline Single cross & Tzi3 X C92 & 8.44 & 66.67 & 129.28 & 1.74 \\
\hline Single cross & VHCY X EM11-133 & 8.4 & 67 & 127.44 & 2.61 \\
\hline Single cross & Tzi3 X VHCY & 7.78 & 62 & 114.67 & 2.53 \\
\hline Parent & C92 & 7.77 & 68.33 & 142.67 & 1.34 \\
\hline Single cross & $\mathrm{C} 92 \times \mathrm{VHCY}$ & 7.65 & 64 & 134.56 & 1.58 \\
\hline Hybrid check & H 513 & 7.51 & 66.44 & 121.5 & 3.76 \\
\hline Single cross & EM11-133 X CML197 & 7.47 & 75.22 & 149.67 & 2.72 \\
\hline Hybrid check & H 614 & 6.95 & 75.44 & 164.22 & 3.68 \\
\hline Parent & EM11-133 & 6.14 & 75 & 133.33 & 3.06 \\
\hline Parent & Tzi3 & 5.42 & 67.89 & 90.22 & 2.55 \\
\hline Parent & VHCY & 4.39 & 63.78 & 88.06 & 2.07 \\
\hline Parent & CML202 & 3.94 & 76.44 & 91.44 & 1.89 \\
\hline Inbred check & EM12-210 & 3.93 & 71.22 & 102.11 & 3.63 \\
\hline Parent & CML197 & 3.56 & 83.78 & 117.94 & 2.44 \\
\hline Mean & & 7.8 & 69.25 & 131.31 & 2.39 \\
\hline Isd & & 0.975 & 1.645 & 11.097 & 0.361 \\
\hline
\end{tabular}

$\mathrm{GY}=$ grain yield $\left(\mathrm{t} \mathrm{ha}^{-1}\right), \mathrm{DTS}=$ days to silking, $\mathrm{EHT}=$ ear height, $\mathrm{MSV}=$ maize streak virus score (scale 1-5)

Three parents showed potential as seed parents, i.e. C92, EM11-133 and Tzi3 with 7.7, 6.1 and 5.4 $\mathrm{t} \mathrm{ha}^{-1}$ respectively since they were higher yielding $(p<0.05)$ than the inbred check, EM12-210 (3.9 t ha $\left.{ }^{-1}\right)$. Despite 
the good performance of single cross CML197 $X$ CML202 in terms of high grain yield, its parents were the least yielding; CML197 with $3.6 \mathrm{t} \mathrm{ha}^{-1}$ and CML202 with $3.9 \mathrm{t} \mathrm{ha}^{-1}$.

There were significant differences among GCA and SCA effects for grain yield; both GCA (48.2\%) and SCA $(51.8 \%)$ were equally important for this trait (Table 3). The association of both GCA and SCA with grain yield concurs with other findings (Nass et al.,
2000; Machado et al., 2009; Qi et al., 2010). The observation that GCA $x$ location interaction was highly significant and greater than SCA $x$ location interaction also agreed with other authors (Nass et al., 2000; Paterniani et al., 2000; Bello and Olaoye, 2009). However, since SCA x environment interaction was generally non-significant, stability of SCA effects across environments was indicated as similarly observed by Machado et al. (2009).

Table 3. Combined analyses of variance for grain yield, agronomic traits, and MSV disease severity across three locations: Embu, Kiboko and Muguga, Kenya in 2009

\begin{tabular}{|c|c|c|c|c|c|}
\hline & & \multicolumn{4}{|c|}{ Mean squares } \\
\hline Source & DF & GY & DTS & EHT & MSV \\
\hline ENV & 2 & $139.329 * \star \star$ & $3898.067^{\star \star \star *}$ & 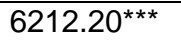 & 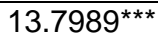 \\
\hline REP (ENV) & 6 & $2.37^{\mathrm{ns}}$ & $7.98^{\star}$ & $404.54^{*}$ & $0.0355^{\mathrm{ns}}$ \\
\hline Crosses & 14 & $13.09 * \star \star$ & $95.97^{\star \star \star}$ & $1883.96^{\star \star \star}$ & $2.2071^{\star \star \star}$ \\
\hline Crosses $\times$ ENV & 28 & $4.05^{\star \star \star}$ & $4.64^{\star}$ & $214.96^{\star}$ & $0.0503^{\star}$ \\
\hline GCA & 5 & $17.659^{\star \star \star}$ & $248.2^{\star \star \star}$ & $4769.585^{\star \star \star}$ & $2.3104^{\star \star \star}$ \\
\hline SCA & 9 & $10.552^{\star \star \star}$ & $11.4^{\star \star \star}$ & $280.838^{\star \star}$ & $0.0236^{\mathrm{ns}}$ \\
\hline $\mathrm{GCA}^{\star} \mathrm{ENV}$ & 5 & $9.489 * \star \star$ & $5.017^{\mathrm{ns}}$ & $416.12^{\star \star}$ & $0.0886^{\star *}$ \\
\hline SCA*ENV & 9 & $0.82^{\text {ns }}$ & $4.102^{\text {ns }}$ & $170.19^{\mathrm{ns}}$ & $0.1967^{\mathrm{ns}}$ \\
\hline Error & 84 & 1.11 & 2.803 & 152.045 & 0.01997 \\
\hline mean & & 9.167 & 65.58 & 139.99 & 2.19 \\
\hline Isd & & 0.988 & 1.569 & 11.559 & 0.18 \\
\hline \multicolumn{6}{|c|}{ Percent contribution of GCA and SCA to crosses sums of squares } \\
\hline GCA & & $48.2 \%$ & $92.4 \%$ & $90.4 \%$ & $98.2 \%$ \\
\hline SCA & & $51.8 \%$ & $7.6 \%$ & $9.6 \%$ & $1.8 \%$ \\
\hline
\end{tabular}

Significance levels ${ }^{* \star}=p<0.001,{ }^{*}=p<0.01$ and ${ }^{*}=p<0.05 ;$ ns $=$ non-significance

$\mathrm{GY}=$ grain yield $\left(\mathrm{t} \mathrm{ha}^{-1}\right)$, DTS= days to silking, $\mathrm{EHT}=$ ear height, $\mathrm{MSV}=$ maize streak virus score $(1-5)$

Two parents, CML197 (0.919***) and CML202 $\left(0.693^{\star \star \star}\right)$ had the highest positive and significant GCA for grain yield, and thus contributed positive alleles in the crosses in which they were involved (Table 4). The three highest positive and significant SCAs were observed in crosses Tzi3 $X$ VHCY $\left(1.928^{\star * \star}\right)$, C92 X EM11-133 (1.192***) and CML197 $X$ CML202 $\left(1.20^{\star \star *}\right)$. Most of the other SCA estimates were generally negative, low or non-significant. It would be expected that the three crosses, which had the highest SCA, would liberate more variability in the segregating generations. This study also found that except in two crosses, CML197 X CML202 and C92 $X$ EM11-133, high SCA for grain yield was not consistent with high yield performance, similar to the results of Xingming et al. (2001).

Days to silking: In all the genotypes evaluated, CML197 was the latest to silk (84 days), and therefore contributed to late maturing single crosses where it was a parent (Table 2). The contrast was observed with parent VHCY, which was the earliest parent (64 days). There were significant differences among GCA and SCA effects for days to silking
(Table 3). The percent contribution of GCA and SCA sum of squares to crosses sum of squares was $94.2 \%$ and $7.6 \%$ respectively, indicated that additive effects contributed majorly towards this trait. The importance of additive genetic effects in influencing days to silking has been reported before (Glover et al., 2005; Menkir and Ayodele, 2005). Based on GCA effects, CML197 and VHCY contributed to lateness and earliness as they had the highest positive $\left(3.972^{\star \star *}\right)$ and negative (3.194**) GCAs respectively, for days to silking (Table 4). It was also noted that although VHCY and Tzi3 were poor combiners for grain yield, they had negative GCA for days to silking, which could be used to introgress earliness into promising lines such as CML197.

Ear height: Ear height among the genotypes tested variably ranged from $88 \mathrm{~cm}$ in parent VHCY to 164 $\mathrm{cm}$ in H614, a hybrid check (Table 2). There were significant differences among GCA and SCA effects for ear height but this trait was also highly influenced by additive effects since GCA contributed $90.4 \%$ to the crosses sum of squares (Table 3 ). Most of the SCA estimates were non-significant further indicating that performance of crosses for ear height was 
dependent on GCA effects. Predominance of additive genetic effects in influencing ear height has been reported by other authors (Glover et al., 2005; Menkir and Ayodele, 2005). The parents that acted additively to shorten the stature of their crosses were VHCY ($\left.3.19^{\star \star \star}\right)$ and Tzi3 $\left(-13.1^{\star \star \star}\right)$ (Table 4) while CML197 $\left(14.31^{\star *}\right)$ contributed to increasing ear height. Since short stature and, early varieties, are more desirable for mid-altitude areas, parents VHCY and Tzi3 could similarly be used to introgress shortness into this inbred line. One such single cross, Tzi3 X CML197 was found to be short, $142 \mathrm{~cm}$, and the $2^{\text {nd }}$ highest yielding hybrid thus showing that short plants can be developed while maintaining high grain yields if this single cross was used as a parent.

MSV disease: Among the parents, C92 had the lowest MSV score of 1.13 confirming its near immunity status (Clerget et al., 1996); contrasting
EM11-133 had the highest score of 3.06 indicating its susceptibility (Gichuru, 2008) (Table 2). The average MSV scores for these single crosses were respectively was 2.19 and 2.23 , which deviated little or not at all from the mid -parent values, thus suggesting co-dominance effects were at play. Storey and Howland (1967) also observed that heterozygotes between resistant and susceptible lines reacted to infection in a manner intermediate between the parents where neither allelomorph was fully dominant. The lowest MSV scores were obtained in cross C92 X CML202 (1.44), which was also relatively high yielding. Most of the single crosses had moderate symptoms but these did not adversely affect the yield potential suggesting presence of tolerance to MSV. For the susceptible checks, their yield potential was nonetheless adversely reduced by MSV infection.

Table 4. Estimates of GCA and SCA for maize yield, agronomic traits, and MSV disease score across three locations: Embu, Kiboko and Muguga

\begin{tabular}{|c|c|c|c|c|}
\hline \multirow[b]{2}{*}{ Inbred lines } & \multicolumn{4}{|c|}{ GCA estimates } \\
\hline & GY & DTS & EHT & MSV \\
\hline CML202 & $0.693^{\star \star *}$ & $-0.194^{\mathrm{ns}}$ & $-0.523^{\mathrm{ns}}$ & $-0.122^{\star \star \star}$ \\
\hline CML197 & 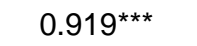 & $3.972^{* \star *}$ & $14.310 * * *$ & $0.103^{\star *}$ \\
\hline EM11-133 & $-0.379^{*}$ & $1.861^{\star \star \star}$ & $3.394^{\mathrm{ns}}$ & $0.391^{\star \star \star}$ \\
\hline VHCY & $-0.947^{\star \star \star}$ & $-3.194^{\star \star \star}$ & $-13.579 \star \star \star *$ & $0.0045^{\mathrm{ns}}$ \\
\hline C92 & $0.008^{\mathrm{ns}}$ & $-0.222^{\mathrm{ns}}$ & $9.491^{\star \star \star}$ & $-0.608^{\star \star \star}$ \\
\hline \multirow[t]{2}{*}{ Tzi3 } & $-0.295^{\mathrm{ns}}$ & $-2.222^{\star \star \star}$ & $-13.093^{\star * *}$ & $0.232^{\star \star \star}$ \\
\hline & \multicolumn{4}{|c|}{ SCA estimates } \\
\hline Single crosses & GY & DTS & EHT & MSV \\
\hline CML197 X CML202 & 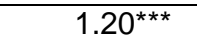 & $0.089^{\text {ns }}$ & $4.883^{\mathrm{nS}}$ & $0.045^{\mathrm{ns}}$ \\
\hline EM11-133 X CML202 & $-0.137^{\mathrm{ns}}$ & $-0.689^{\mathrm{ns}}$ & $-3.978^{\text {ns }}$ & $-0.022^{\mathrm{ns}}$ \\
\hline VHCY X CML202 & $0.142^{\mathrm{ns}}$ & $-0.189^{\mathrm{ns}}$ & $-0.450^{\mathrm{ns}}$ & $-0.006^{\mathrm{ns}}$ \\
\hline C92 X CML202 & $-0.436^{\mathrm{ns}}$ & $0.950^{*}$ & $1.258^{\mathrm{ns}}$ & $-0.025^{\mathrm{ns}}$ \\
\hline Tzi3 X CML202 & $-0.770 * \star$ & $-0.161^{\mathrm{ns}}$ & $-1.714^{\mathrm{ns}}$ & $0.008^{\mathrm{ns}}$ \\
\hline EM11-133 X CML197 & $-2.235^{\star \star \star}$ & $1.811^{\star \star \star}$ & $-8.033^{*}$ & $0.012^{\mathrm{ns}}$ \\
\hline VHCY X CML197 & $0.027^{\mathrm{ns}}$ & $-0.244^{\mathrm{ns}}$ & $2.828^{\mathrm{ns}}$ & $-0.109 *$ \\
\hline C92 X CML197 & $0.268^{\mathrm{ns}}$ & $-1.328 * \star$ & $-0.297^{\mathrm{ns}}$ & $0.076^{\mathrm{ns}}$ \\
\hline Tzi3 X CML197 & $0.740 * \star$ & $-0.328^{\mathrm{ns}}$ & $0.619^{\mathrm{ns}}$ & $-0.025^{\mathrm{ns}}$ \\
\hline VHCY X EM11-133 & $0.559 *$ & $0.756^{\mathrm{ns}}$ & $-2.367^{\mathrm{ns}}$ & $-0.003^{n s}$ \\
\hline C92 X EM11-133 & $1.192^{\star \star \star}$ & $-0.994^{*}$ & $7.508^{*}$ & $0.033^{\mathrm{ns}}$ \\
\hline Tzi3 X EM11-133 & $-0.717^{\mathrm{ns}}$ & $-1.661^{*}$ & $-1.992^{\mathrm{ns}}$ & $-0.087^{\mathrm{ns}}$ \\
\hline $\mathrm{C} 92 \times \mathrm{VHCY}$ & $-0.581^{*}$ & $-0.161^{\mathrm{ns}}$ & $-1.353^{\mathrm{ns}}$ & $-0.002^{\mathrm{ns}}$ \\
\hline Tzi3 X VHCY & 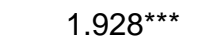 & $0.411^{\mathrm{ns}}$ & $4.894^{\mathrm{ns}}$ & $-0.073^{\mathrm{ns}}$ \\
\hline Tzi3 X C92 & $-0.147^{\mathrm{ns}}$ & $-0.161^{\mathrm{ns}}$ & $1.342^{\mathrm{ns}}$ & $0.120^{\mathrm{ns}}$ \\
\hline
\end{tabular}

Significance levels ${ }^{* * *}=p<0.001,{ }^{* *}=p<0.01$ and ${ }^{*}=p<0.05 ; \quad$ ns $=$ non-significance

$\mathrm{GY}=$ grain yield $\left(\mathrm{t} \mathrm{ha}^{-1}\right)$, DTS= days to silking, EHT= ear height, MSV=maize streak virus disease (score 1-5) 
There were significant differences among GCA effects for MSV scores but SCA effects were generally non-significant (Table 3). A high GCA (98\%): SCA (2\%) ratio was observed for MSV resistance suggesting that additive effects were important in the experience of for this trait. The importance of additive gene effects for MSV resistance has been reported in several other studies (Caulifield, 1997; Dintinger et al., 1997; Nhlane, 1997; Pixley et al., 1997; Vivek et al., 2010). For leaf diseases, negative values of GCA and SCA indicate genetic contribution to expressed resistance. Thus parents CML202 $\left(-0.122^{\star \star \star}\right)$ and C92 $\left(-0.608^{\star \star \star}\right)$ showed the most negative GCA for MSV (Table 4), and, therefore, the most desirable sources for useful resistance.

High yielding, early maturing, MSV disease resistant genotypes are of great importance to the maize producing areas of Kenya. Putative materials meeting these criteria were identified in this study since a high level of resistance to MSV was present, supported by earliness and high grain yields in the crosses. It is also crucial to note that the experimental materials included lines that are highly adapted to the Kenyan environments, e.g., CML202 and EM11-133. Single cross EM11-133 X CML202 was observed to combine desirable traits, i.e., high yield $\left(9.34 \mathrm{t} \mathrm{ha}^{-1}\right)$, early maturity (69 days), short stature $(139 \mathrm{~cm})$, and MSV disease resistance (score 2.47).

There were high GCA influences and thus per se line performances should be good indicators of the performance of resulting hybrids. Nevertheless, since GCA interacted highly with environments there is a need to select specific parents for hybrid formation in specific niches. This shows that except for grain yield, non-additive gene action played a minor role in the inheritance of other traits: days to silking, ear height, and MSV resistance. Hallauer and Miranda Filho (1988) also found dominance effects to bemore important for grain yield than for other traits such as plant height and ear height. Several researchers have similarly indicated the importance of additive effects in the inheritance of different agronomic traits (Ligeyo, 2000; Vacaro et al., 2002). The importance of additive gene effects in controling MSV resistance has resistance also been observed for other major foliar diseases: gray leaf spot (Menkir and Ayodele, 2005; Vanegas-Angaritas et al., 2007; Derera et al., 2008; Vieira et al., 2009; Vivek et al., 2010), and northern leaf blight (Vieira et al., 2009). Overall, therefore, selection schemes utilizing additive effects would appear to be the most appropriate to improve maize foliar disease resistance.

It was also observed that although CML197 and CML202 had the highest GCA, had the highest grain yield in their cross, and possessed positive and significant SCA, these lines have been grouped in the same heterotic group "A" (CIMMYT, 2004). This indicated that heterotic groups could change with environments of growth, and with different testers. Parent Tzi3 gave a low GCA for grain yield but was found to be a good combiner for earliness and short stature with inbred line CML197. This combination could be studied further with the view of extracting parental lines for use in developing superior hybrids for grain yield, earliness and short stature. Inbred lines CML202 and C92 had negative GCA effects for MSV and therefore they contributed towards resistance to the disease. These two lines have been widely accepted as sources of MSV resistance in Africa (Clerget et al., 1996; Benti et al., 1997; Welz et al., 1998; Pernet et al., 1999a). CML202 was also reported to be a good source of resistance to multiple disease, i.e., gray leaf spot and northern leaf blight, in addition to MSV (Asea et al., 2009). The high yields of C92 and EM11-133 both as single cross and as parents under disease infection showed that their productivity was not affected by the disease, making this single cross the strongest candidate for release as a cultivar to farmers.

Several of the exotic lines used in this study, i.e., CML202, CML197, and Tzi3 have been introgressed into locally adapted lines, EM12-210 and EM11-133, information of base populations to be used in pedigree breeding programs for the mid-altitude areas of Kenya. This study therefore contributed towards a guided exploitation of the MSV resistance sources through understanding of the genetic relationships among the adapted lines used. Thus the lines could be used systematically in breeding varieties that are high yielding, agronomically appealing and having durable MSV resistance, where local varieties are susceptible to the disease.

\section{CONCLUSION}

The physical expression of the MSV disease in this study showed great differentiation, which was most probably reflective of the diverse nature of the germplasm used. Results show that single crosses involving the germplasm not only yielded significantly more grain and possessed better agronomic value than the check varieties but also contained potentially good seed and pollen parents. Some of these 
materials, for instance CML 197 and CML 202, have known adaptation to the Eastern Africa Region. The MSV resistant cross (CML197xCML202) produced $60 \%$ more grain than the best check variety used, and was early, a clearly desirable feature in the target environment. Thus this cross should be evaluated further for commercial use. As a male, CML 202 also combined with C92, a near immune line, to produce a single cross that had the lowest MSV scores and yielded high amounts of grain. Good performance was however subject to the vagaries of the environment of test, a factor that greatly influenced the type and level of genetic effects controlling such performance. Associated with this observation was the finding that heterotic grouping of lines is not absolute in the sense that it can substantially be altered both by the tester used and by the environment of test.

Similar to results of previously published work, grain yields were found to be under both GCA and SCA. Apparently, GCA effects interact highly with the environments of production while SCA effects are much more stable. Crosses with high SCA should be used to generate genetic variability to permit selection in appropriately segregating generations. Also earliness, as measured by days to silking, and short plant stature assessed by ear-height above ground, are controlled principally by additive effects, and hence should respond well if selection was practiced on the germplasm used in this study. Evidence was adduced showing that both codominant forces and additive effects mainly controlled the resistance to MSV present. From these results, it is concluded that the materials used in this study contained useful sources of MSV resistance, desirable grain yield potential and heterotic selections useful to breeders in Eastern Africa, in the altitudes of between 900 and 2000 meters above sea level, where rampant MSV presence has been a great constraint to production of maize.

\section{ACKNOWLEDGEMENTS}

The authors would like to appreciate the Kenya Agricultural Research Institute for providing resources and the Rockefeller foundation for funding this work.

\section{REFERENCES}

Asea, G., Vivek, B.S., Bigirwa, G., Lipps, P.E and Pratt, R.C (2009). Validation of consensus quantitative trait loci associated with resistance to multiple foliar pathogens of maize. Phytopathology 99: 540-547.

Baker, R.J (1978). Issues of diallel analysis. Crop Sci. 18: 533-536.
Bello, O.B and Olaoye, G (2009). Combining ability for maize grain yield and other agronomic characters in a typical southern guinea savanna ecology of Nigeria. Afri. J. Biotechnol. 8: 2518-2522.

Benti, T., Mulata, K., Wolde, L., Wolku, M and Tulu, L. (1997). Reflections on the successful achievements of hybrid maize breeding program in Ethiopia. In: Ransom (ed.). Maize Productivity gains through research and technology dissemination. Fifth Eastern and Southern Africa Regional Maize Conference Arusha Tanzania. CIMMYT, Addis Ababa, Ethiopia.

Bock, K.R (1974). Maize Streak virus. No. 133. In : Descriptions of plant viruses. Ann. Appl. Biol. 77: 289296.

Caulifield, M.J (1997). Genotype reaction to streak and mottle virus in maize In: Proceedings of the 1st international Maize streak disease symposium. September 9-11, 1997, Hazyview, Mpumalanga

Clerget, B., Dintiger, J and Reynaud, B (1996). Registration of maize inbred CIRAD 390 parental line. Crop Sci. 36: 826.

Derera, J., Tongoona, P., Pixley, K.V., Vivek, B., Laing, M.D and van Rij, N.C (2008). Gene action controlling gray leaf spot resistance in southern African maize germplasm. Crop Sci. 48: 93-98.

Diallo, A (1999). CIMMYT and MSV. In: Advances in maize streak virus disease research in eastern and southern Africa, workshop report. ISAAA Briefs No.16. ISAAA, 15-17 September 1999, Nairobi, Kenya. KARI and ISAAA AfriCenter.

Dintinger, J., Pernet, A., Rodier, A., Reynaud, B and Marchaund, L (1997). A complete resistance to maize streak virus originating in mascarene germplasm, inheritance and gene mapping In: Proceedings of the 1st international Maize streak disease symposium. September 9-11, 1997, Hazyview, Mpumalanga.

Gichuru, L.N (2008). Combining ability for grain yield and other agronomic traits and F1 maize streak virus disease expression in diverse genotypes of maize (Zea Mays L.). MSc. Thesis, University of Nairobi.

Glover, M.A., Willmot, D.B., Darrah, L.L., Hibbard, B.E and Zhu, X (2005). Diallel analyses of agronomic traits using chinese and U.S. maize germplasm. Crop Sci. 45: 1096-1102.

Griffing, B (1956b). Concepts of general and specific combining ability in relation to diallel crossing systems. Aust. J. of Biol. Sci. 9: 463-493.

Ininda, J., Snape, J and Opondo, R.O (1999). DNA polymorphisms among sources of MSV resistance and disease expression in F2 and F3-derived lines. In: Advances in maize streak virus disease research in eastern and southern Africa, workshop report. ISAAA Briefs No.16. ISAAA, Nairobi, Kenya. KARI and ISAAA AfriCenter. 
Leuschner, K and Buddenhagen, I.W (1980). Screening for resistance to maize streak virus: An improved method of field infection. IITA Research briefs 1: 4-6.

Ligeyo, D.O (2000). A diallel analysis of yield and yield component traits in crosses involving maize (Zea mays) inbred lines. In: EA Mukhisira et al. (ed.). Proceedings of the KARI 7th biennual conference. 1317th November 2000, KARI headquarters Nairobi.

Machado, J.C., de Souza, J.C., Ramalho, M.A and Lima, J.L (2009). Stability of combining ability effects in maize hybrids. Scien. Agric. 66: 494-498.

Magenya, O.E.V., Mueke, J and Omwega, C (2008). Significance and transmission of maize streak virus disease in Africa and options for management: A review. Afri. J. Biotechnol. 71: 4897-4910.

Martin, D.P and Shepherd, D.N (2009). The epidemiology, economic impact and control of maize streak disease. Food Sec. 1: 305-315.

Menkir, A and Ayodele, M (2005). Genetic analysis of resistance to gray leaf spot of midaltitude maize inbred lines. Crop Sci. 45: 163-170.

Nass, L.L., Lima, M., Vencovsky, R and Gallo, P.B (2000). Combining ability of maize inbred lines evaluated in three environments in Brazil. Science and Agriculture 57: $129-134$

Nhlane, W.G (1997). Genetic analysis of maize streak virus disease in Maize. In: Proceedings of the 1st international Maize streak disease symposium. September 9-11, 1997, Hazyview, Mpumalanga.

Paterniani, M.E., Dudienas, C and Gallo, P.B (2000). Diallel crosses among maize lines with emphasis on resistance to foliar diseases. Genet. Mol. Biol. 23: 381385.

Pernet, A., Hoisington, D., Dintiger, J., Jewell, D., Jiang, C., Khairallah, M., Letourmy, P., Marchand, J.L., Glaszmann, J.C and Gonzalez, de Leon D (1999a). Genetic mapping of maize streak virus resistance from the Mascarene source. II. Resistance in line CIRAD390 and stability across germplasm. Theor. Appl. Genet. 99: 540-553.

Pernet, A., Hoisington, D., Franco, J., Isnard, M., Jewell, D., Jiang, C., Marchand, J.L., Reynaud, B., Glaszman, J.C and Gonzalez, de Leon D (1999b). Genetic mapping of maize streak virus resistance from the Mascarene source. I. Resistance in line D211 and stability against different virus clones. Theor. Appl. Genet. 99: 524-539.

Pixley, K.V., Jewell, D., Schechert A and Welz, G. (1997). Recent Maize streak Disease research at CIMMYT Zimbabwe. In: Proceedings of the 1st international Maize streak disease symposium. September 9-11, 1997, Hazyview, Mpumalanga.

Qi. X., Kimatu, J.N., Li, Z., Jiang, L., Cui, Y and Liu, B (2010). Heterotic analysis using AFLP markers reveals moderate correlation between specific combining ability and genetic distance in maize inbred lines. Afri. J. Biotechnol. 9: 1568-1572.

Rodier, A., Assie, J., Marchand, J.L and Herve, Y (1995). Breeding maize lines for complete and partial resistance to maize streak virus (MSV). Euphytica 81: $57-70$

SAS Institute Inc (1999). SAS/STAT user's guide. Version 8. (SAS. Institute Inc., Cary NC).

Shoyinka, S.A (1988). Cereal viruses in Africa. In: Virus diseases of plants in Africa. W. A. Olufemi .(ed.) pp. 59 -73. (OAUSTRC scientific publication Lagos, Nigeria: International institute of Tropical Agriculture, Ibadan Nigeria).

Soto, P.E., Buddenhaggen, I.W and Asnani, V.L (1982). Development of streak virus resistant maize populations through improved challenge and selection methods. Ann. Appl. Biol. 100: 539-546.

Storey, H.H and Howland, A.K (1967). Transfer of resistance to the streak virus into East Africa Maize. EAAFRO Jour. 33: 131-135.

Vacaro, E., Neto, J.F., Pegoraro ,D.G., Nuss, C.N and Conceicao, L.D ( 2002). Combining ability of twelve maize populations. Pesq. Agropec. Bras. 37: 67-72.

van Rensburg, G.D.J (1981). Effect of plant age at the time of infection with maize streak virus on yield of maize. Phytophylactica 13: 197-198.

Vanegas-Angaritas, H., De-Leon, $\mathrm{C}$ and Narro-Leon, L (2007). Genetic analysis of tolerance to Cercospora spp. in tropical maize inbred lines. Agrociencia 41: 3543.

Vieira, R.A., Scapim, C.A., Moterle, L.M., Tessmann, D.J., Conrado, T.V and Amaral Junior, A.T (2009). Diallel analysis of leaf diseases resistance in inbred Brazilian popcorn cultivars. Genetics and Molecular Research 8: 1427-1436.

Vivek, B.S., Odongo, O.M., Njuguna, J., Imanywoha, J., Bigirwa, G., Diallo, A and Pixley, K (2010). Diallel analysis of grain yield and resistance to seven disease of 12 African maize (Zea mays L.) inbred lines. Euphytica 172: 329-340.

Welz, H.G., Schechert, A., Pernet, A., Pixley, K.V and Geiger, H.H (1998). A gene for resistance to the maize streak virus in the African CIMMYT maize inbred line CML 202. Mol. Breed. 4: 147-154.

Xingming, F., Jing, T., Bihua ,H and Feng, L. (2001). Analyses of combining ability and heterotic groups of yellow grain quality protein maize inbreds. In: Seventh Eastern and Southern Africa Regional Maize conference. 11th -15th February, 2001. 